\title{
Titanát nanoszerkezetek és fémek felületi kölcsönhatásai: ioncsere vagy klaszterképződés?
}

\author{
MADARÁSZ Dániel, ${ }^{\mathrm{a}}$ KUKOVECZ Ákos ${ }^{\mathrm{b}}, \mathrm{KISS} \mathrm{János}^{\mathrm{c}}$ és KÓNYA Zoltán ${ }^{\mathrm{a}, \mathrm{c},}$, \\ ${ }^{a}$ Szegedi Tudományegyetem, 6720 Szeged, Rerrich Béla tér 1. \\ ${ }^{b}$ MTA-SZTE „Lendület” Pórusos Nanokompozitok Kutatócsoport, 6720 Szeged, Rerrich Béla tér 1. \\ ${ }^{c}$ MTA-SZTE Reakciókinetikai és Felületkémiai Kutatócsoport, 6720 Szeged, Rerrich Béla tér 1.
}

\section{1. Általános bevezetés az 1D struktúrákról}

Az egydimenziós (1D) nanoszerkezetek (nanocsövek, nanoszálak, nanorudak) története a szén nanocsövek felfedezésével kezdődött1, de napjainkra már számos egyéb anyagból sikerült 1D-s struktúrát elöállítani (ezüst, réz, wolfram-oxid, cérium foszfát, titán-dioxid vagy az ebben a dolgozatban is tárgyalt trititanát) ${ }^{2-6}$. Közös tulajdonságuk, hogy igen nagy hossz/keresztmetszet aránnyal rendelkeznek. Az 1D-s nanostruktúrák szerkezetüknek köszönhetően tulajdonságaikban eltérnek a tömbfázisú anyagoktól. Nagy a fajlagos felületük és a kvantum korlátozottság (,quantum confinement”) miatt különleges elektromos, optikai és kémiai tulajdonságokat mutatnak.

\section{Titanát nanocsövek és nanoszálak előállítása, jellemzése}

A titanát nanocsövek és nanoszálak előállítása alkáli hidrotermális eljárással történik. $\mathrm{TiO}_{2}$ és $10 \mathrm{M}$-os $\mathrm{NaOH}$ homogén szuszpenzióját reagáltatjuk 24 órán át teflon bélésü autoklávban $150-190{ }^{\circ} \mathrm{C}-\mathrm{on}^{7,8}$. Az autoklávot rövidebb tengelye körül forgatjuk. Lassú forgatás és alacsonyabb hőmérséklet mellett csöves, míg gyorsabb forgatással magasabb hőmérsékleten szálas morfológiájú szerkezeteket kapunk. A nyersterméket híg savval és desztillált vízzel mossuk a feleslegben lévő lúg közömbösítése céljából. A mosás paramétereitől függően a kész termékben a $\mathrm{Na}^{+} / \mathrm{H}^{+}$ arány változó lehet.

A nanocsövek szerkezetét „szőnyegszerüen” feltekeredett titanát lapok alkotják. A csövek végei nyitottak, átlagos hosszuk 80-100 nm, átlagos átmérőjük 5-8 nm. Egy-egy nanocsőfal átlagosan 3-4 rétegü, a rétegek közötti távolság $\sim 0,7 \mathrm{~nm}$. Szerkezetéből adódóan a nanocső igen nagy, 230 $\mathrm{m}^{2} / \mathrm{g}$ fajlagos felülettel rendelkezik. A feltekeredett trititanát lapot egymáshoz éleiken kapcsolódó $\mathrm{TiO}_{6}$ oktaéderek alkotják. Az oktaéderekből álló negatív töltésű vázat ioncsere pozíciókban lévő $\mathrm{Na}^{+}, \mathrm{H}^{+}$ionok vagy egyéb kationok semlegesítik.

A nanoszálak a nanocsövek összekapcsolódásával, majd a szerkezet összeroppanásával alakulnak ki, ezért feltekeredett lapkák helyett itt párhuzamos trititanát rétegek alkotják a szerkezetet. A szintén $\mathrm{TiO}_{6}$ oktaéderes építőegységekből álló rétegek végeiken nyitottak. Átlagos hosszuk 2-5 $\mu \mathrm{m}$, vastagságuk $80-100 \mathrm{~nm}$. A nanoszálak fajlagos felülete a nanocsövekénél jóval kisebb, kb. $30 \mathrm{~m}^{2} / \mathrm{g}$.

\footnotetext{
* Kónya Zoltán. Tel.: +36 62 544-620; fax: +36 62 544-619; e-mail: konya@chem.u-szeged.hu
}

\section{Ioncsere és klaszterképződés titanát nanoszerkezeteken}

A közelmúltban számos olyan közlemény látott napvilágot, melyekben részletesen kimutatták, hogy a titanát nanocsövek és nanoszálak jelentős mértékben tudnak fémeket különböző formában a felületükön és szerkezetükben stabilizálni. A titanát nanoszerkezetek ioncsere kapacitásuknak köszönhetően képesek fémionokat nagy mennyiségben beépíteni. Többek között Pt, Pd, Au, Ni részecskéket és fém-hidroxidokat lehet immobilizálni a pórusokon vagy pórusokban, majd a megkötött anyagok további morfológiai változásokat szenvedhetnek a különböző kezeléseknek köszönhetően ${ }^{5,9} \cdot \mathrm{Pb}^{2+}, \mathrm{Cd}^{2+}, \mathrm{Cu}^{2+}$ és $\mathrm{Cr}^{3+}$ ionok titanát nanocsövön történő adszorpciója során kitűnt a nagy adszorpciós kapacitás ${ }^{10}$, mely a következő sorrendben változott: $\mathrm{Pb}^{+}>>\mathrm{Cd}^{+}>\mathrm{Cu}^{+}>>\mathrm{Cr}^{3+}$. A fémionok $\left(\mathrm{M}=\mathrm{Ce}^{4+}, \mathrm{La}^{3+}, \mathrm{Co}^{2+}, \mathrm{Cu}^{2+}\right)$ interkalálódhatnak a titanát nanocsőben és helyettesíthetik a nátriumot vagy a protont ${ }_{11}$. A titanátok viszonylag nagy fajlagos felülete és sajátos felület fizikai és kémiai sajátságai lehetővé teszik, hogy nemcsak fémionok, hanem fém klaszterek és fém nanorészecskék is kialakuljanak, így bővítve a titanátok fölhasználási területét főként a katalízisben, fotokatalízisben. Dolgozatunkban részletesen foglalkozunk a $\mathrm{Co}, \mathrm{Au}$ és a $\mathrm{Rh}$ beépülésével és a titanátokkal való kölcsönhatásukkal.

\subsection{Ioncsere és klaszterképződés a Co mennyiségének függvényében titanát nanoszálon}

A kobalt adalékolás folyamatát az esetek nagy többségében az nehezíti, hogy a prekurzor molekulák termikus bomlása során függetlenül attól, hogy klorid, nitrát vagy más kobalt sóból indulunk ki, a termikus bomlás során oxid képződik. A kialakult kobalt-oxidot nagyon nehéz redukálni még magas hőmérsékleten is, ráadásul a titanátok esetében a magas hőmérsékletű redukció a titanát szerkezet károsodását eredményezi. Ezt kiküszöbölendő kobalt-karbonil $\left(\mathrm{Co}_{2}(\mathrm{CO})_{8}\right)$ prekurzor molekulát alkalmaztunk ${ }^{12}$. A kobalt adalékolás az egyik legjobb példa arra, hogy a mennyiségtől függően különböző minőségű kobalt formátumokat tudunk a titanát felületen létrehozni.

$\mathrm{Az}$ adszorbeált $\mathrm{Co}_{2}(\mathrm{CO})_{8}$ diffúz reflexiós infravörös spektruma (DRIFTS) az 1. ábrán látható. $\mathrm{A} \mathrm{Co}_{2}(\mathrm{CO})_{8} \mathrm{C}_{2 \mathrm{v}}$ csoport szimmetriának megfelelően híd-szerkezetü $\mathrm{CO}$ csoportok jelentek meg 1986 és $2036 \mathrm{~cm}^{-1}$-nél, két gyengébb intenzitású csúcs 1928 és $1872 \mathrm{~cm}^{-1}$-nél volt látható. Ezek az 
IR csúcsok teljesen eltüntek $623 \mathrm{~K}$-en, jelezvén, hogy a karbonil teljesen elbomlott, miközben a gázfázisban kizárólag $\mathrm{CO}_{2}$-t mutattunk ki.

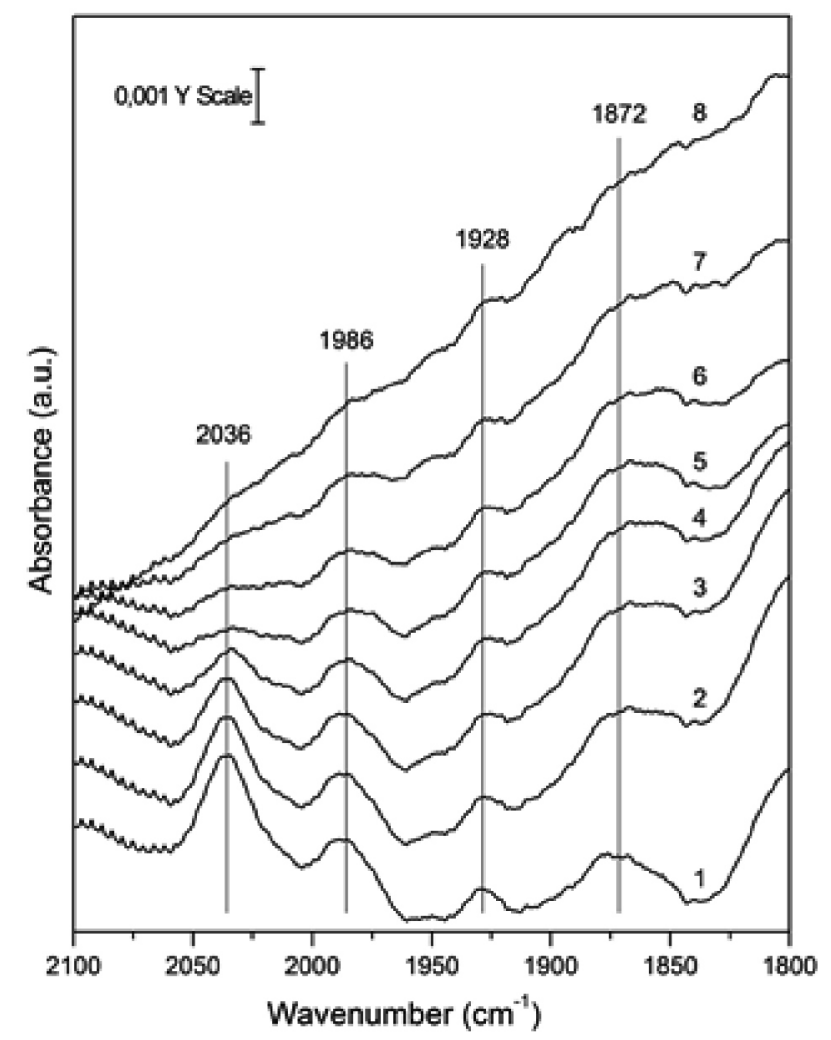

1. ábra. Az adszorbeált Co2(CO) 8 DRIFT spektrumai protonált titanát nanoszálon $327 \mathrm{~K}$-en és az azt követő felfütés után: $1-323 \mathrm{~K}, 2-373 \mathrm{~K}$, $3-423 \mathrm{~K}, 4-473 \mathrm{~K}, 5-523 \mathrm{~K}, 6-573 \mathrm{~K}, 7-623 \mathrm{~K}, 8-673 \mathrm{~K}$. A spektrumok az adott hőmérsékleten lettek felvéve $1 \mathrm{~cm}-1$ felbontást alkalmazva.

A bomlás során a $\mathrm{CO}$ ligandum reagált a titanát felületi oxigénjével $^{13}$. A DRIFT és a hömérséklet programozott deszorpciós (TPR) spektrumok megegyeztek a különböző mennyiségü kobalt-karbonil prekurzor molekula alkalmazásakor: 2 és $4 \mathrm{wt} \%$ kobalt-karbonil is ugyanazt az eredményt mutatta. A felületi és szerkezeti változások azonban minőségileg eltértek.

2 wt\% karbonil adalékolás után látható klaszterképződést, részecskéket nem tudtunk kimutatni a transzmissziós elektronmikroszkópiás (TEM) felvételeken. Alacsony dópolás után a minta színe a sárgásról intenzív sárgára változott. Az UV-Vis spektrumokból meghatároztuk a tiltott sáv (,bandgap”) értékeket (Eg), melyeket a Beranek-Kish ${ }^{14}$ által ajánlott eljárás alapján számítottuk az $\alpha=\mathrm{A}\left(\mathrm{h} v-\mathrm{E}_{\mathrm{g}}\right)^{\mathrm{n}}$ / hv egyenlet alapján, ahol az $\alpha$ az adszorpciós koefficiens, $\mathrm{n}=2$ feltételezve az indirekt, ,bandgap”-et. Az $\mathrm{E}_{\mathrm{g}}$ értéke a Co mentes mintán mért 3,14 eV-röl 2,48 eV-re csökkent 2 wt\% karbonil adalékolásig. A Co tartalmat növelve további $\mathrm{E}_{\mathrm{g}}$ csökkenést nem tapasztaltunk. A Co $2 p_{3 / 2}$ fotoemissziós csúcsa 787.8 eV-nál jelent meg ennél az alacsony dópolási értéknél a karbonil bomlása után, mely jellemző a $\mathrm{Co}^{2}+$ ionra. Mindezek a megfigyelések arra mutatnak, hogy kis mennyiségű Co adalékolás során kizárólag ioncsere történik.
Növelve a kobalttartalmat, a TEM képeken Co részecskéket mutattunk ki. 4 wt\% Co tartalom esetén 2-6 nm közötti részecskéket találtuk (2. ábra).

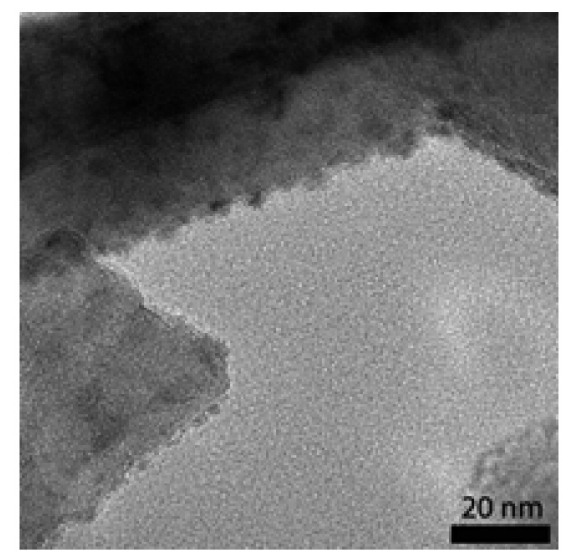

2. ábra. Co-al adalékolt titanát nanoszál TEM képe.

Részletes XPS vizsgálatokkal követtük a Co kémiai környezetét a Co-karbonil bomlása előtt, illetve a teljes bomlást követően, valamint további hőkezelés után (3. ábra).

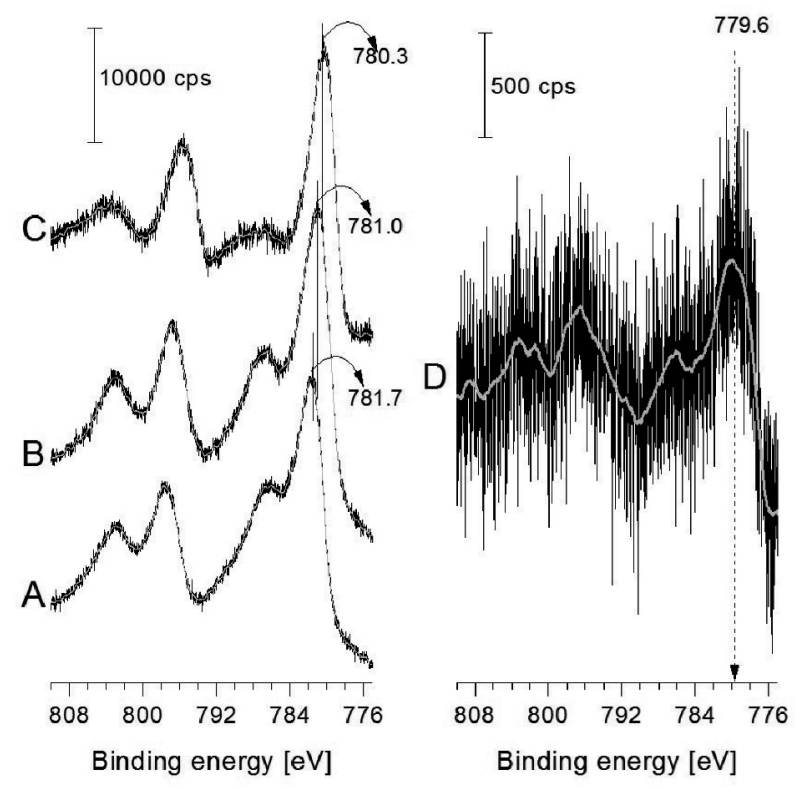

3. ábra. A Co 2p3/2 csúcsai a karbonil adszorpció után 327 K-en (A), 600 K-en történt karbonil bontás után (B), $600 \mathrm{~K}$-en 60 perces oxigénes kezelés után $(\mathrm{C}), 600 \mathrm{~K}$-en 60 perces kezelés után (D).

A karbonil adszorpciója után a Co $2 \mathrm{p}_{3 / 2}$ XPS csúcsát 787,7 eV-nál találtuk, a Co $2 \mathrm{p}^{1 / 2} 797.5$ eV-nál helyezkedik el, a molekulának megfelelő szatellitek szintén megtalálhatók a spektrumokon ${ }^{15}$. Lényeges megállapítás, hogy a bomlás után Co veszteség nem látható a Co csúcs intenzitásban, de a fotoemissziós csúcs eltolódik $781.0 \mathrm{eV}$-ra. Ez az érték magasabban van, mint a fémes kobalté ${ }^{16}$. Ez a megállapítás arra enged következtetni, hogy a képződött Co egy, a titanát szerkezetéből adódóan speciális oxigénkörnyezetben helyezkedik el. $600 \mathrm{~K}$-en oxigénes kezelés után $\mathrm{CoO}$ szerkezet alakul $\mathrm{ki}^{17}$. 
A kobalt adalékolásra és beépülésre vonatkozó legfóbb megállapításunk az, hogy alacsony kobalttartalomnál kizárólag ioncsere folyamat játszódik le, míg növelve a kobalt mennyiségét kobalt részecskék alakulnak ki, melyek oxidációs állapota a fémes kobalténál nagyobb.

\subsection{Arany kölcsönhatása titanát nanoszállal és nanocsővel}

Az arany a leginkább vizsgált fém a különböző szerkezetü $\mathrm{TiO}^{2}$-on és titanátokon. Ennek az az oka, hogy az $\mathrm{Au} / \mathrm{TiO}_{2}$ nanoszerkezetek a legelterjedtebb fotokatalizátorok közé tartoznak ${ }^{18-20}$. A másik fó ok pedig az, hogy $\mathrm{Au} / \mathrm{TiO}_{2}$ már nagyon alacsony hőmérsékleten katalizál ipari és környezetkémiai szempontból fontos folyamatokat, beleértve a $\mathrm{CO}$ alacsonyhőmérsékletü oxidációját ${ }^{21}$. Továbbá az is kiderült, hogy a CO és hidrogén oxidáció számára a titanát nanocsőre felvitt Au jobb katalizátor, mint a Degussa típusú TiO2-on kialakított arany ${ }^{22}$.

Atomosan diszperz aranyat pórusos $\mathrm{TiO}_{2}$-on és titanát nanoszerkezeteken együttlecsapással vagy depoziciósprecipitációs módszerekkel lehet előállítani ${ }^{21-25}$. Bár szigorúan véve teljesen monodiszperz részecskéket nem lehet előállítani, az utóbbi évek erőfeszítései nyomán 2-10 nm közötti átlagos átmérővel már sikerült kontrollált rendszereket létrehozni ${ }^{21-27}$. A 4. ábrán két különböző módon titanát nanoszálra felvitt aranyrészecskék TEM képei láthatók. A 4A ábrán az arany só $\left(\mathrm{HAuCl}_{4}\right)$ bomlása után 473 K-en hidrogénnel történő redukciót alkalmaztunk, hogy fémes aranyat kapjunk, míg a 4B ábrán a redukciót 273 K-en $\mathrm{NaBH}_{4}$-al végeztük. Látható, hogy az utóbbi esetben kisebb méretü és homogénebb eloszlást értünk el.
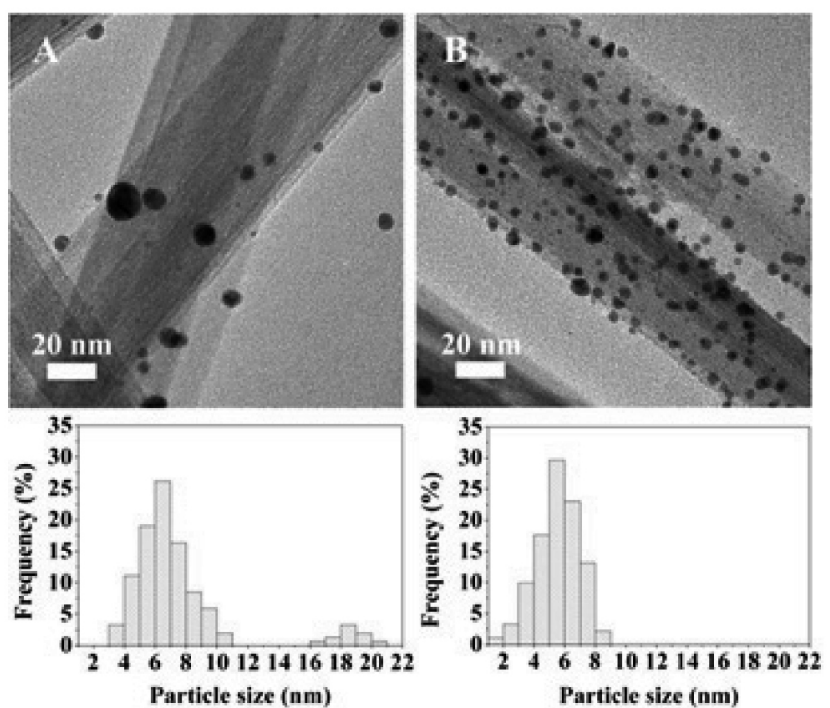

4. ábra Titanát nanoszálon kialakított arany nanorészecskék TEM képei hidrogénes redukcióval (A), borohidrides redukcióval (B)

A titanátokra felvitt arany kémiai környezetét XPS-el jellemeztük. Az arany $4 \mathrm{f}$ spektrumait a különböző szerkezeteken és különböző redukciós eljárások után az 5. ábrán mutatjuk be. Összehasonlításként az ábra mutatja az üveg felületen létrehozott tiszta arany filmről $(50 \mathrm{~nm})$ felvett spektrumot is. A $4 \mathrm{f}$ tartományban szimmetrikus $4 \mathrm{f}_{5 / 2}$ és $4 \mathrm{f}_{7 / 2}$ emissziókat detektáltunk ( $5 \mathrm{~A}$ ábra). A titanátokon azonban ettől eltérő spektrumot észleltünk (5B-D ábrák). Fémes állapotra jellemző $4 \mathrm{f}_{7 / 2}$ jel 84,0 eV-nál jelent meg, emellett csúcs jelentkezett $85,8-86,3 \mathrm{eV}$ között is.

Jelenleg két hipotézissel magyarázhatjuk ezt a szokatlanul magas energiájú fotoemissziót. A különböző részecskeméreteknek a törzselektronok eltolódására gyakorolt hatását kétségkívül figyelembe kell venni ${ }^{28-30}$. Ugyanakkor annak ellenére, hogy a részecskeméret jelentős szerepet játszik, önmagában a $2 \mathrm{eV}$-os eltolódást nem lehet teljesen a kis részecskeméretek jelenlétének tulajdonítani. A második elképzelés szerint az arany ioncsere folyamatban vesz részt. $\mathrm{Ez}$ nem lehetséges $\mathrm{TiO}_{2}$-on, de nagy valószínüséggel megtörténhet titanátokon a jól ismert ioncsere képességüknek köszönhetően ${ }^{31}$.

\section{$\mathrm{Au} 4 \mathrm{f}$}
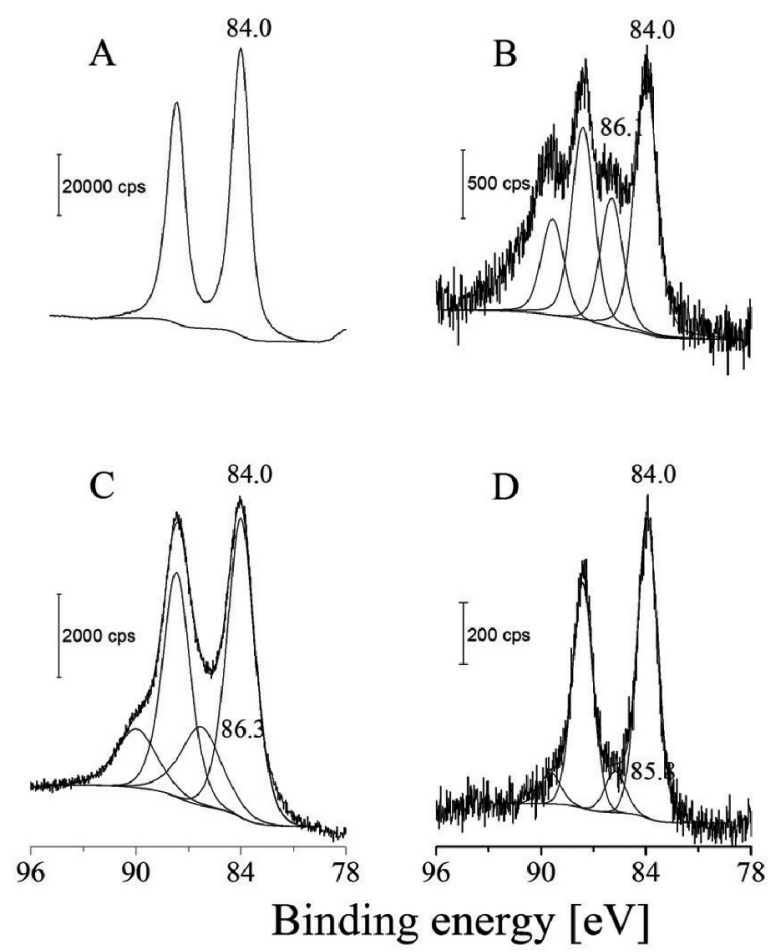

5. ábra. Au 4f spektrumai; (A) Au film üvegen, (B) 1 wt \% Au titanát nanoszálon hidrogénes redukció után, (C) $2.5 \mathrm{wt} \%$ Au titanát nanoszálon hidrogénes redukció után, (D) 2,5 wt\% Au titanát nanoszálon borohidrides redukció után.

Az ioncsere megtörténtére XPS-független bizonyítékunk is van, nevezetesen a tiltott sáv szélessége lecsökken arany adalékolás hatására. Cheng és munkatársai elméletileg bizonyították, hogy az ioncsere együtt jár a tiltott sávszélesség csökkenésével hasonló rendszerben $(\text { Ni-magnetit })^{32}$. A fentiekben leírt módon meghatároztuk a tiltott sáv szélességeket a különböző összetételü rendszereken és azt tapasztaltuk, hogy az értékek csökkentek $\sim 0,4 \mathrm{eV}$-al. Kisebb csökkenést mértünk, ha az aranyat $\mathrm{NaBH}_{4}$-es módszerrel redukáltuk. A különböző Tauc függvényeket a 6 . ábrán mutatjuk be. 

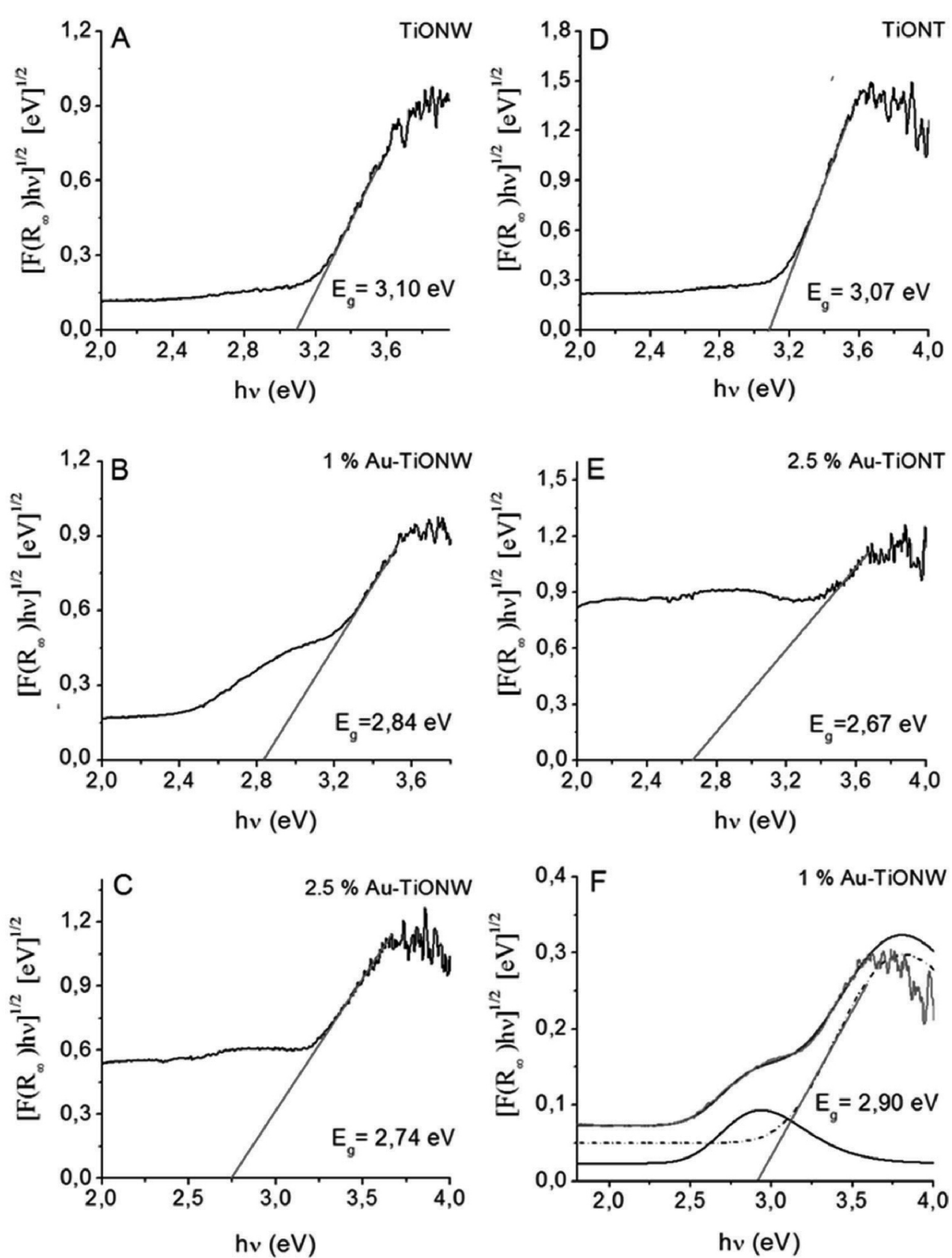

- Suggested absorbance of AuNC's (Gauss, $422 \mathrm{~nm}, 3.03 \mathrm{eV}$ ) — Au-TiONW ...... Suggested absorbance of Au-TiONW (Gauss) - Sum of Gauss fit

6. ábra. Tauc görbék különböző arany depozitok után; (A) és (D) aranymentes titanát nanoszál és nanocső, (B) 1 wt \% Au nanoszálon, (C) 2,5 wt\% Au nanoszálon, (E) 2,5 wt\% Au nanocsövön, (F) 1 wt\% Au nanoszálon, fölbontott spektrum.

$\mathrm{Az}$ arany helyi felületi plazmonikus karaktere lényegében átfedheti az $\mathrm{O} 2 \mathrm{p} \rightarrow \mathrm{Ti} 3 \mathrm{~d}$ átmenetet, ezért a részletes adat meghatározása érdekében csúcsfelbontást alkalmaztunk az 1 wt $\%$ esetében nanoszálon ( $6 \mathrm{~F}$ ábra). A felületi plazmonikus sávval a 3 nm-nél nagyobb átmérőjü részecskék esetén számolhatunk. E méret alatt az arany fémes jellege megszünik, és a kollektív elektronokra jellemző, 2,4-2,5 eV-nál mutatkozó plazmonikus sajátsággal nem kell számolni. A 6F ábrán 2,5 és 3,2 eV között kimutatott széles sáv tehát nagy valószínüséggel molekulaklaszterek jelenlétére utal. A közelmúltban $\mathrm{Au}_{25}$ klaszterekre mutattak ki molekulaszerü átmeneteket az optikai abszorpciós spektrumokon 1,8 eV, 2,75 eV és 3,1 eV-nál ${ }^{33}$. Itt jegyezzük meg, hogy a sávszélesség csökkenése, a plazmonikus sajátságok jelenléte, valamint a molekulaszerü klaszterek jelenléte egyenként is, de együttesen még inkább hozzájárulnak a titanáton hordozott arany jelentős fotokatalitikus viselkedéséhez. Összehasonlításként megemlítjük, hogy az ezüst is képes ioncsere folyamatban részt venni, valamint hogy nagyobb dotálásnál klaszterképződést is megfigyeltek titanát nanocsövön DRIFTS és TEM módszerekkel ${ }^{34}$. 
A fentiek alapján azt a következtetést vonhatjuk le, hogy az XPS-ben megjelenő nagyobb energiájú csúcs (85,8-86,4 eV) elsősorban a kationpozícióban levő Au-nak $\left(\mathrm{Au}^{+}\right)$ köszönhetö, és - valamelyest kisebb mértékben - azoknak a klasztereknek (pl. $\mathrm{Au}$ atomok egy $\mathrm{Au}_{25}$ klaszterben) amelyeket a titanát térszerkezet stabilizál. Ez a két hatás függ a fémtartalomtól és a fém előállítás módjától is. Figyelemre méltó az XPS intenzitások hőmérsékletfüggése, amelyet a 7. ábrán mutatunk be. Amikor az aranytartalmú (2,5 wt\%) titanát nanoszálat 473 K-ről 673 K-re fütöttük vákuumban, a csúcspozíció maradt 86,4 eV-nál, azonban az intenzitás enyhén csökkent (7A ábra).

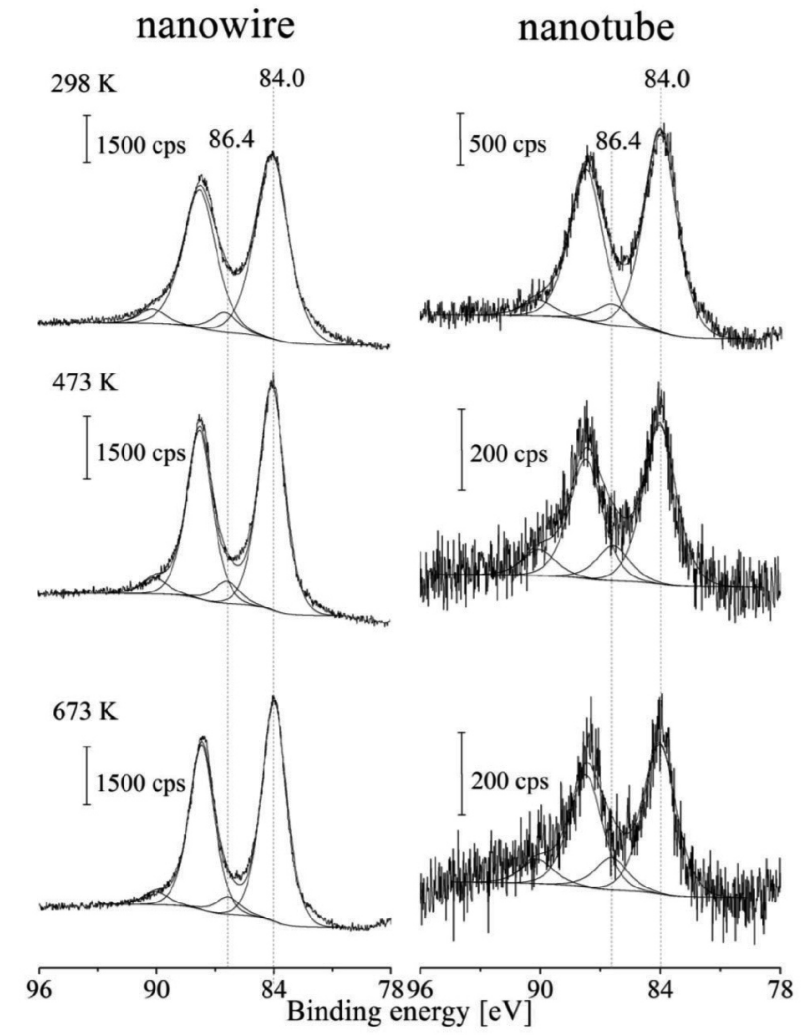

7. ábra. Au 4f XP spektrumai titanát nanoszálon (A) és nanocsövön (B) 2,5 wt\% Au tartalomnál a különböző vákuumban történő hőkezelések után.

Ez azt jelenti, hogy a hőkezelés nem okozott jelentős aranyszegregációt az ioncsere pozícióból. Érdekes azonban, hogy ugyanez az aranymennyiség kisebb Au 4f XPS intenzitást eredményezett a nanocső esetében (7B). Nagyon valószínü tehát, hogy az arany klaszterek jelentős hányada a cső belsejében helyezkedett el a cső külső palástja helyett. Az XPS analízis alapján megtehető közelítő becslés szerint az arany mennyiségének $75 \%$-a van a cső belsejében. További intenzitáscsökkenést ( $50 \%)$ mértünk, ha a mintát $473 \mathrm{~K}$ fölé fütöttük. Ez a változás azt jelenti, hogy további aranypenetráció történt a cső belsejébe.

\subsection{Rh nanorészecskék jellemzése titanát nanoszálon és nanocsövön}

A hordozós Rh katalizátorok használata elterjedt számos technológiában, beleértve a $\mathrm{CO}_{2}$ hidrogénezését is. Kimutatták, hogy a hordozó jelentősen befolyásolja a Rh specifikus aktivitását, továbbá a $\mathrm{Rh}$ előidézheti a hordozó morfológiai változását is ${ }^{35-39}$. Laboratóriumunkban részletesen vizsgáltuk a Rh felületkémiai sajátságait titanát nanoszerkezeteken TEM-el, XRD-vel, Raman spektroszkópiával, DRIFTS-el és XPS-el ${ }^{39}$.
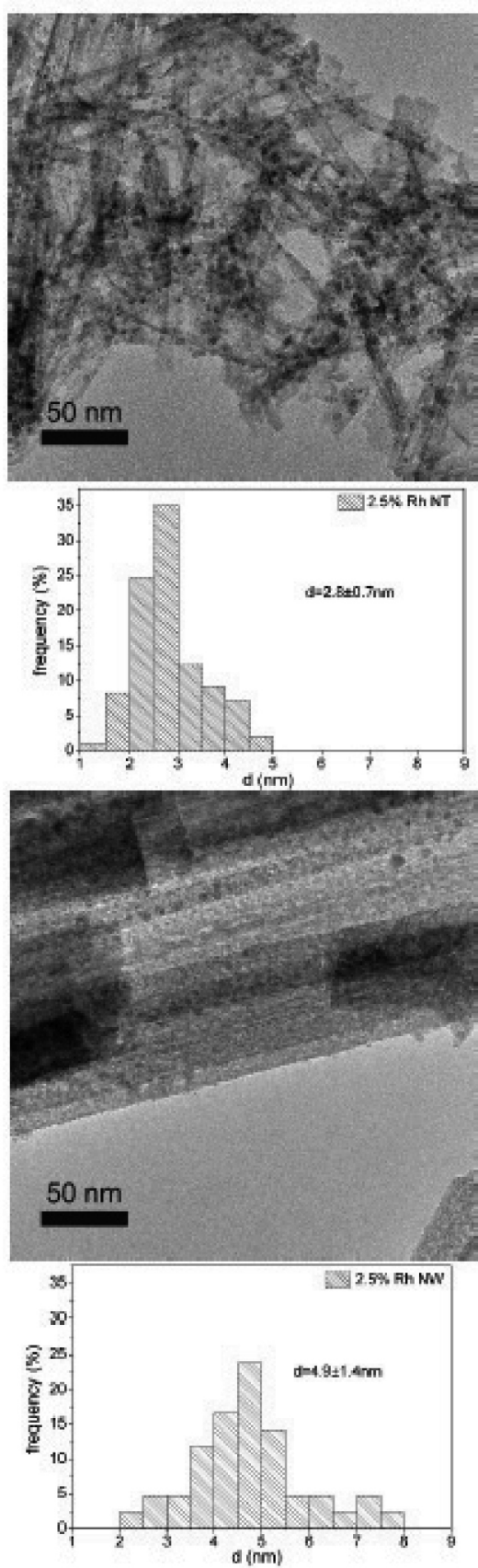

8. ábra. A 2.5 wt\% tartalmú nanoszálon (A) és nanocsövön (B) kialakult Rh TEM képe és a megfelelő részecskátmérö-eeloszlások 673 K hőkezelés után. 
A $\mathrm{Rh}$ depozitot a titanátok $\mathrm{RhCl}_{3} \times 3 \mathrm{H}_{2} \mathrm{O}$ só (Johnson Matthey) oldatával történő impregnálásával állítottuk elő. Az impregnált mintákat levegőn szárítottuk 383 K-en 3 óráig. A végső kezelés hidrogén atmoszférában történt 473-573 K-en ${ }^{24,39-42}$. A 8. ábrán a nanoszálon és nanocsövön kialakított Rh nanorészecskék TEM képei láthatók. Feltüntettük a kialakult részecskeátmérö- eloszlásokat is.

Az átlagos részecskeméret a nanoszálon 4,9 $\pm 1,4 \mathrm{~nm}$, a nanocsövön pedig 2,8 $\pm 0,7 \mathrm{~nm}$ a $673 \mathrm{~K}$-es hőkezelés után. $\mathrm{Az}$ átlagos részecskeméretben és az eloszlások kiszélesedésben mutatkozó eltérések a különböző fázisátalakulási folyamatokkal magyarázhatók ${ }^{39}$. Továbbá a felületi diffúzió és $\mathrm{Rh}$ nanorészecskék koaleszcenciás kinetikája a nanocsövön és a szálformán különbözö lehet.
Fontosnak tartjuk megjegyezni, hogy annak ellenére, hogy a redukciót a fémes Rh létrehozására 473-573 K-en végeztük viszonylag kisméretü Rh részecskéket sikerült létrehozni, azaz a titanát nanoszerkezet képes a kis méret stabilizációjára. Rendezett $\mathrm{TiO}_{2}$ felületeken a $\mathrm{Rh}$ nanorészecskék agglomerizációja már $500 \mathrm{~K}$ alatt is jelentős az STM, XPS ${ }^{43,44}$ és LEIS ${ }^{45}$ mérések szerint. A nanoszálon és nanocsövön kapott viszonylag kis méret azt jelzi, hogy ezeken a titanát struktúrákon a ródium diffúziója korlátolt. A TEM mérésekkel összhangban vannak XPS eredményeink is.

A Rh 3d photoemisszós csúcsait 1 és 2 wt \% Rh-t tartalmazó nanoszálon és nanocsövön a 9. ábrán mutatjuk be.

B
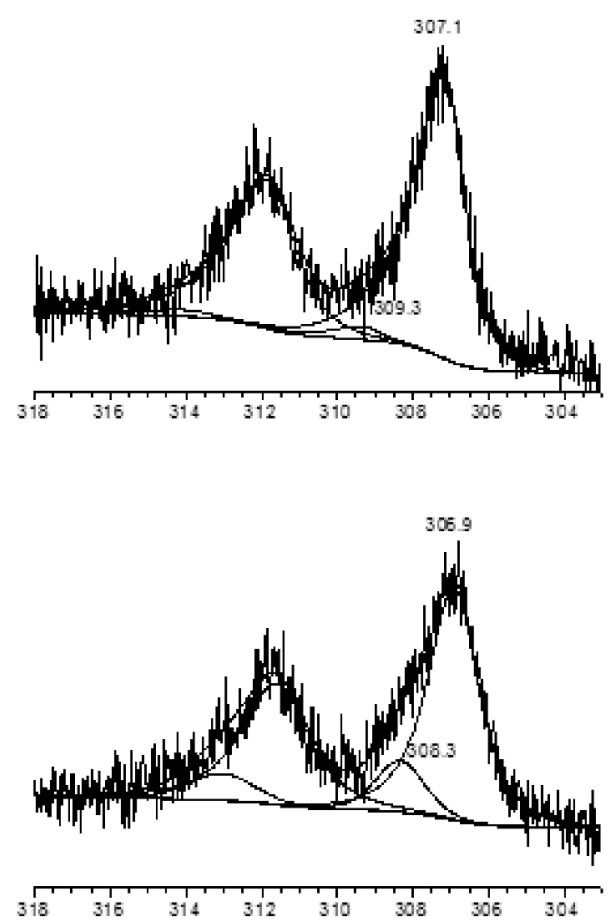

Binding energy [eV]

9. ábra. Rh 3d XP spektruma nanoszálon (A) és nanocsövön 1 wt\% (felső spektrumok) és 2 wt\% (alsó spektrumok) Rh tartalomnál.

1 wt \% fémtartalomnál a Rh 3d jele 309.3 eV-nál jelentkezett, 2 wt\%-nál pedig 308,3 eV-nál, a fémes karakterü tömbi fázishoz rendelt csúcsok viszont 307,1 és 306,9 eV-nál detektálhatók. A fémes karakterhez képest tehát $1 \mathrm{wt} \% \mathrm{Rh}$ felvitele esetén közel 2,2 eV-os eltolódást találtunk, 2 wt \% $\mathrm{Rh}$ esetén pedig ez a relatív eltolódás $1.2 \mathrm{eV}$. A nanorészecskék méreteloszlásából következően bizonyos mértékü csúcskiszélesedés nem zárható ki (8. ábra). A nagyobb kötésenergiájú fotoemissziós csúcsok a kisméretü klasztereknek tulajdoníthatók, ugyanis a kötésenergiákat a relaxációs energia is befolyásolja, ami a részecskemérettől függ ${ }^{28}$. Amint az arany nanorészecskék esetén is láttuk, kisebb méret nagyobb kötésenergiákat eredményezhet. A nagyobb kötésenergiák megjelenését a fémről a hordozóra történő töltéstranszfer is elöidézheti. A Rh és a $\mathrm{TiO}_{2}$ közötti, fóként hibahelyekhez köthető erős elektromos kölcsönhatás jól ismert ${ }^{46-48}$. A titanát nanoszerkezetek sok hibahelyet tartalmaznak, így a kölcsönhatás még erősebb is lehet.

Másrészről nem zárhatjuk ki, hogy ioncsere folyamat játszódik le a protonált titanát és a Rh között, mint ahogy ez bebizonyosodott már többek között az ezüsttel és az arannyal adalékolt titanátokon ${ }^{25,34}$. Adszorbeált $\mathrm{CO}$ molekulát, mint próbamolekulát alkalmazva sikerült parciális töltésü Rh részecskéket kimutatni. Mind a Rh-t tartalmazó nanoszálon, mind a nanocsövön a domináns FTIR sáv a dikarbonil forma, jelei 2028 és $2097 \mathrm{~cm}-1$-nél jelentek meger,41. A sávintenzitások különbözők a nanoszálon és a nanocsövön. 
Ezek a különbségek a klaszterméretben mutatkozó eltérésekre és a különböző mértékü fém-hordozó kölcsönhatásra vezethetők vissza. Mindezek a hatások szerepet játszanak a fémindukált fázistranszformációban, ami magyarázhatja, hogy a Rh-al dekorált nanoszál miért alakul át $\beta-\mathrm{TiO}_{2}$-vé, míg a nanocső esetében az anatázzá történő átalakulás megy végbe.

\section{Hivatkozások}

1. Iijima, S. Nature 1991, 354, 56. https://doi.org/10.1038/354056a0

2. Hong, B. H.; Bae, S. C.; Lee, C.-W.; Jeong, S.; Kim, K. S. Science 2001, 294, 348. https://doi.org/10.1126/science.1062126

3. Szabo, M.; Pusztai, P.; Leino, A. R.; Kordas, K.; Konya, Z.; Kukovecz, A. Journal of Molecular Structure 2013, 1044, 99. https://doi.org/10.1016/j.molstruc.2012.11.041

4. Pusztai, P.; Simon, T.; Kukovecz, A.; Konya, Z. Journal of Molecular Structure 2013, 1044, 94.

https://doi.org/10.1016/j.molstruc.2012.11.042

5. Bavykin, D. V.; Walsh, F. C. Titanate and Titania Nanotubes: Synthesis, Properties and Applications; RSC Publishing: Cambridge, 2010. https://doi.org/10.1039/9781849730778

6. Kukovecz, A.; Kordás, K.; Kiss, J.; Kónya, Z. Surf. Sci. Rep. 2016, 71, 473.

https://doi.org/10.1016/j.surfrep.2016.06.001

7. Horvath, E.; Kukovecz, A.; Konya, Z.; Kiricsi, I. Chemistry of Materials 2007, 19, 927. https://doi.org/10.1021/cm062413q

8. Kukovecz, A.; Hodos, N.; Horvath, E.; Radnoczi, G.; Konya, Z.; Kiricsi, I. J Phys Chem B 2005, 109, 17781. https://doi.org/10.1021/jp054320m

9. Bavykin, D. V.; Lapkin, A. A.; Plucinski, P. K.; Torrente-Murciano, L.; Friedrich, J. M.; Walsh, F. C. Top Catal 2006, 39, 151.

https://doi.org/10.1007/s11244-006-0051-4

10. Liu, W.; Wang, T.; Borthwick, A. G. L.; Wang, Y.; Yin, X.; Li, X.; Ni, J. Science of The Total Environment 2013, $456-457,171$. https://doi.org/10.1016/j.scitotenv.2013.03.082

11. dos Santos, N. M.; Rocha, J. M.; Matos, J. M. E.; Ferreira, O. P.; Filho, J. M.; Viana, B. C.; Oliveira, A. C. Applied Catalysis A: General 2013, 454, 74. https://doi.org/10.1016/j.apcata.2012.12.035

12. Suvanto, S.; A. Pakkanen, T.; Backman, L. Applied Catalysis A: General 1999, 177, 25. https://doi.org/10.1016/S0926-860X(98)00253-1

13. Madarasz, D.; Potari, G.; Sapi, A.; Laszlo, B.; Csudai, C.; Oszko, A.; Kukovecz, A.; Erdohelyi, A.; Konya, Z.; Kiss, J. Physical Chemistry Chemical Physics 2013, 15, 15917. https://doi.org/10.1039/c3cp51502h

14. Beranek, R.; Kisch, H. Photoch Photobio Sci 2008, 7, 40. https://doi.org/10.1039/B711658F

15. Ho, S. W.; Houalla, M.; Hercules, D. M. J Phys Chem-Us 1990, 94, 6396. https://doi.org/10.1021/j100379a045

16. Zsoldos, Z.; Guczi, L. J Phys Chem-Us 1992, 96, 9393. https://doi.org/10.1021/j100202a061
17. Biesinger, M. C.; Payne, B. P.; Grosvenor, A. P.; Lau, L. W. M.; Gerson, A. R.; Smart, R. S. C. Applied Surface Science 2011, 257, 2717.

https://doi.org/10.1016/j.apsusc.2010.10.051

18. Subramanian, V.; Wolf, E. E.; Kamat, P. V. Journal of the American Chemical Society 2004, 126, 4943.

https://doi.org/10.1021/ja0315199

19. Tian, Y.; Tatsuma, T. Journal of the American Chemical Society 2005, 127, 7632. https://doi.org/10.1021/ja042192u

20. Ola, O.; Maroto-Valer, M. M. J Photoch Photobio C 2015, 24, 16. https://doi.org/10.1016/j.jphotochemrev.2015.06.001

21. Haruta, M. Catalysis Today 1997, 36, 153. https://doi.org/10.1016/S0920-5861(96)00208-8

22. Akita, T.; Okumura, M.; Tanaka, K.; Ohkuma, K.; Kohyama, M.; Koyanagi, T.; Date, M.; Tsubota, S.; Haruta, M. Surf Interface Anal 2005, 37, 265. https://doi.org/10.1002/sia.1979

23. Malwadkar, S. S.; Gholap, R. S.; Awate, S. V.; Korake, P. V.; Chaskar, M. G.; Gupta, N. M. J Photoch Photobio A 2009, 203, 24. https://doi.org/10.1016/j.jphotochem.2008.12.013

24. Kukovecz, A.; Potari, G.; Oszko, A.; Konya, Z.; Erdohelyi, A.; Kiss, J. Surface Science 2011, 605, 1048. https://doi.org/10.1016/j.susc.2011.03.003

25. Pusztai, P.; Puskas, R.; Varga, E.; Erdohelyi, A.; Kukovecz, A.; Konya, Z.; Kiss, J. Physical Chemistry Chemical Physics 2014, 16, 26786. https://doi.org/10.1039/C4CP04084H

26. Boccuzzi, F.; Chiorino, A.; Manzoli, M.; Lu, P.; Akita, T.; Ichikawa, S.; Haruta, M. Journal of Catalysis 2001, 202, 256. https://doi.org/10.1006/jcat.2001.3290

27. Chen, G. L.; Xue, F.; Chen, Z. L.; Si, X. L.; Zheng, X.; Huang, J.; Massey, S. Nano 2014, 9. https://doi.org/10.1142/S1793292014500398

28. Henry, C. R. Surface Science Reports 1998, 31, 231. https://doi.org/10.1016/S0167-5729(98)00002-8

29. Peters, S.; Peredkov, S.; Neeb, M.; Eberhardt, W.; Al-Hada, M. Surface Science 2013, 608, 129. https://doi.org/10.1016/j.susc.2012.09.024

30. Kiss, J.; Pusztai, P.; Óvári, L.; Baán, K.; Merza, G.; Erdőhelyi, A.; Kukovecz, A.; Kónya, Z. e-Journal of Surface Science and Nanotechnology 2014, 12, 252. https://doi.org/10.1380/ejssnt.2014.252

31. Madarasz, D.; Szenti, I.; Sapi, A.; Halasz, J.; Kukovecz, A.; Konya, Z. Chemical Physics Letters 2014, 591, 161. https://doi.org/10.1016/j.cplett.2013.11.021

32. Huang, J. R.; Hsu, H.; Cheng, C. J Magn Magn Mater 2014, 358, 149. https://doi.org/10.1016/j.jmmm.2014.01.048

33. Zhu, M.; Aikens, C. M.; Hollander, F. J.; Schatz, G. C.; Jin, R. Journal of the American Chemical Society 2008, 130, 5883. https://doi.org/10.1021/ja801173r

34. Cesano, F.; Bertarione, S.; Uddin, M. J.; Agostini, G.; Scarano, D.; Zecchina, A. J. Phys. Chem. C 2010, 114, 169. https://doi.org/10.1021/jp9087207

35. Toth, M.; Kiss, J.; Oszko, A.; Potari, G.; Laszlo, B.; Erdohelyi, A. Top Catal 2012, 55, 747. https://doi.org/10.1007/s11244-012-9862-7

36. Solymosi, F.; Erdohelyi, A. J Mol Catal 1980, 8, 471. https://doi.org/10.1016/0304-5102(80)80086-1

37. Henderson, M. A.; Worley, S. D. J Phys Chem-Us 1985, 89, 392. https://doi.org/10.1021/j100249a002

38. Trovarelli, A.; Mustazza, C.; Dolcetti, G.; Kaspar, J.; Graziani, M. Applied Catalysis 1990, 65, 129. https://doi.org/10.1016/S0166-9834(00)81593-6 
39. Potari, G.; Madarasz, D.; Nagy, L.; Laszlo, B.; Sapi, A.; Oszko, A.; Kukovecz, A.; Erdohelyi, A.; Konya, Z.; Kiss, J. Langmuir 2013, 29, 3061. https://doi.org/10.1021/la304470v

40. Kiss, J.; Németh, R.; Koós, Á.; Raskó, J. Journal of Nanoscience and Nanotechnology 2009, 9, 3828. https://doi.org/10.1166/jnn.2009.NS75

41. Oszko, A.; Potari, G.; Erdohelyi, A.; Kukovecz, A.; Konya, Z.; Kiricsi, I.; Kiss, J. Vacuum 2011, 85, 1114. https://doi.org/10.1016/j.vacuum.2010.12.021

42. Kiss, J.; Ovari, L.; Oszko, A.; Potari, G.; Toth, M.; Baan, K.; Erdohelyi, A. Catalysis Today 2012, 181, 163. https://doi.org/10.1016/j.cattod.2011.06.002

\section{Surface interaction of titanate nanostructures with metals: ion exchange or cluster formation?}

The history of one-dimensional (1D) nanostructures started with the discovery of carbon nanotubes, however, recently several other 1D structures (including titanates) have been successfully produced. These materials all feature a high aspect ratio. In this paper, we use the term "nanotube" for high aspect ratio objects with a hollow inner channel and diameter below $50 \mathrm{~nm}$, and "nanowire" for high aspect ratio objects without an inner void and diameter below $200 \mathrm{~nm}$. The 1D nanostructures differ fundamentally from bulk materials. Layered titanates nanomaterials are produced today almost exclusively by the alkaline hydrothermal synthesis. Due to their relatively high surface area and specific physico-chemical properties, titanates are capable of incorporating metallic nanoclusters or metal ions in their framework. In the present work we discuss the interaction of $\mathrm{Co}, \mathrm{Au}$ and $\mathrm{Rh}$ with titanates.

We present the comprehensive study on the structure of cobalt-loaded titanate nanowires obtained by the low-temperature thermal decomposition of $\mathrm{Co}_{2}(\mathrm{CO})_{8}$. The decomposition of $\mathrm{Co}_{2}(\mathrm{CO})_{8}$ was almost complete at 550-600 $\mathrm{K}$. Depending of metal loading, Co was stabilized on titanate nanowires either in $\mathrm{Co}^{2+}$ form by ion exchange or by cluster formation. The chemical nature and morphology of cobalt particles were characterized by X-ray photoelectron spectroscopy and HRTEM. The band gap decreased from
43. Poirier, G. E.; Hance, B. K.; White, J. M. J Phys Chem-Us 1993, 97, 5965. https://doi.org/10.1021/j100124a031

44. Berko, A.; Menesi, G.; Solymosi, F. J Phys Chem-Us 1996, 100, 17732. https://doi.org/10.1021/jp9627638

45. Ovari, L.; Kiss, J. Applied Surface Science 2006, 252, 8624. https://doi.org/10.1016/j.apsusc.2005.11.081

46. Solymosi, F. Catalysis Reviews 1968, 1, 233. https://doi.org/10.1080/01614946808064705

47. Vannice, M. A.; Garten, R. L. Journal of Catalysis 1979, 56, 236. https://doi.org/10.1016/0021-9517(79)90110-6

48. Solymosi, F.; Erdohelyi, A.; Bansagi, T. Journal of Catalysis 1981, 68, 371. https://doi.org/10.1016/0021-9517(81)90106-8

$3.14 \mathrm{eV}$ to $2.41 \mathrm{eV}$ with increasing Co content up to $2 \mathrm{wt} \%$ cobalt content. The significant change in the band gap due to Co loading suggests that cobalt is stabilized in the structure by ion exchange up to $2 \mathrm{wt} \%$ loading. Higher cobalt loadings $(4 \mathrm{wt} \%$ ) lead to the formation of dispersed Co nanoparticles complexed to oxygen vacancies. The average Co particle sizes were between 2 and $6 \mathrm{~nm}$.

The size distribution and homogeneity of gold particles depend on the method used for reducing the dissolved gold salt into deposited nanoparticles. Smaller clusters (3-8 nm) were obtained with $\mathrm{NaBH} 4$ reactant at $293 \mathrm{~K}$ than with molecular hydrogen reduction at $473 \mathrm{~K}$. An unexpectedly high binding energy gold state was found by XPS in gold-loaded titanate nanostructures. A likely explanation for this phenomenon is that depending on the metal loading, Au is stabilized on titanate nanowires partially in positively charged gold form by ion exchange, partially as Au clusters and at low $\mathrm{Au}$ loading probably as very small $\mathrm{Au}_{25}$ clusters, too.

XPS data revealed the existence of high binding energy, highly dispersed $\mathrm{Rh}$ species on nanowires and nanotubes. The high binding energy state is most probably explained by the cluster size effect; however, the electron transfer from $\mathrm{Rh}$ adatoms to the titanate substrate and the formation of partially oxidized states due to ion exchange process cannot be excluded. The average diameter of Rh nanoparticles was $4.9 \pm 1.4 \mathrm{~nm}$ and $2.8 \pm 0.7 \mathrm{~nm}$ in case of nanowires and nanotubes, respectively. 